Article

\title{
Investigation of Water Temperature Variations and Sensitivities in a Large Floodplain Lake System (Poyang Lake, China) Using a Hydrodynamic Model
}

\author{
Yunliang $\mathrm{Li}^{1, *}$, Qi Zhang ${ }^{1,2, *}$, Li Zhang ${ }^{2}$, Zhiqiang $\operatorname{Tan}^{1}$ (D) and Jing Yao ${ }^{1}$ \\ 1 Key Laboratory of Watershed Geographic Sciences, Nanjing Institute of Geography and Limnology, \\ Chinese Academy of Sciences, Nanjing 210008, China; zqtan@niglas.ac.cn (Z.T.); jyao@niglas.ac.cn (J.Y.) \\ 2 Key Laboratory of Poyang Lake Wetland and Watershed Research, Ministry of Education, \\ Jiangxi Normal University, Nanchang 330022, China; zhanglinu@126.com \\ * $\quad$ Correspondence: yunliangli@niglas.ac.cn (Y.L.); qzhang@niglas.ac.cn (Q.Z.); Tel.: +86-025-8688-2125 (Y.L.)
}

Received: 19 October 2017; Accepted: 27 November 2017; Published: 28 November 2017

\begin{abstract}
Although changes in water temperature influence the rates of many ecosystem processes in lakes, knowledge of the water temperature regime for large floodplain lake systems subjected to multiple stressors has received little attention. The coupled models can serve to derive more knowledge on the water temperature impact on lake ecosystems. For this purpose, we used a physically-based hydrodynamic model coupled with a transport model to examine the spatial and temporal behavior and primary causal factors of water temperature within the floodplain of Poyang Lake that is representative of shallow and large lakes in China. Model performance is assessed through comparison with field observations and remote sensing data. The daily water temperature variations within Poyang Lake were reproduced reasonably well by the hydrodynamic model, with the root mean square errors of $1.5-1.9^{\circ} \mathrm{C}$. The modeling results indicate that the water temperature exhibits distinct spatial and temporal variability. The mean seasonal water temperatures vary substantially from $29.1{ }^{\circ} \mathrm{C}$ in summer to $7.7^{\circ} \mathrm{C}$ in winter, with the highest value in August and the lowest value in January. Although the degree of spatial variability differed considerably between seasons, the water temperature generally decreases from the shallow floodplains to the main flow channels of the lake. As expected, the lake water temperature is primarily affected by the air temperature, solar radiation, wind speed and the inflow temperature, whereas other factors such as cloud cover, relative humidity, precipitation, evaporation and lake topography may play a complementary role in influencing temperature. The current work presents a first attempt to use a coupled model approach, which is therefore a useful tool to investigate the water temperature behavior and its major causal factors for a large floodplain lake system. It would have implications for improving the understanding of Poyang Lake water temperature and supporting planning and management of the lake, its water quality and ecosystem functioning.
\end{abstract}

Keywords: Poyang Lake; water temperature; spatial and temporal variability; hydrodynamic model; remote sensing; sensitivity analysis

\section{Introduction}

Lakes are known to be good sentinels, integrators and regulators of climate change, as the physical, chemical and biological properties respond strongly to changes in their environment [1-3]. Water temperature is a key variable in the water quality and hydrodynamic conditions of lakes [4,5], which is expected to influence the rates of many lake ecosystem functioning [6,7]. Therefore, water temperature plays an important role in examining the hydrological and ecological processes over lakes attributed to anthropogenic and natural causes [8-10]. 
High-frequency in situ sensors are commonly used to monitor vertical variations in water temperature in lakes, rivers and other waterbodies; however, such techniques may not be adequate to investigate horizontal changes [11,12]. The use of measurements derived from remote sensing potentially provides an effective tool for assessing the temperature cycle of large lakes $[5,13,14]$. A number of previous investigations into the water temperature changes of large lakes includes Sima et al. [4], who used MODIS land surface temperature products to examine the temperature distribution and associated water loss in the hyper-saline Urmia Lake (Iran). Allan et al. [5] used atmospherically-corrected Landsat thermal imagery to identify the spatial heterogeneity of horizontal water temperature in geothermally-influenced Rotorua Lake and Taupo Lake (New Zealand). The temporal and spatial trends in water temperature of large European lakes (e.g., Geneva Lake, Balaton Lake) were investigated by Politi et al. [15], who demonstrated that the NOAA AVHRR (Advanced Very High Resolution Radiometer) thermal data are capable of acquiring highly accurate lake water temperature. Similar approaches have also been adopted for the North American Laurentian Great Lakes [16] and European Alpine lakes [17]. Nevertheless, the remote sensing data usually restrict tracing the daily or weekly (i.e., short-term) variation of water temperature due to the coarse temporal resolution and hence create high uncertainty for estimating monthly and annual variations in the water temperature of lakes [4].

Physically-based modeling of lake water temperature provides opportunities for interpolating temporal data gaps obtained from remote sensing and routine monitoring data and for extrapolating water temperature to an entire waterbody [5]. Water temperature modeling studies include the application of the 2D hydrodynamic model MIKE 21 by Mahanty et al. [18] to simulate hydrodynamics and temperature variability in the Chilika lagoon (India), who found that the spatial variation of water temperature is mainly influenced by the meteorological conditions, tide and freshwater influx. Bueche and Vetter [19] used the 1D hydrodynamic model DYRESM (Dynamic Reservoir Simulation Model) to investigate the water temperature characteristics of the pre-alpine Ammersee Lake (Germany). They found that the most sensitive reactions of the water temperature in the lake are the air temperature and wind speed. A 3D hydrodynamic model FVCOM (Finite Volume Community Model) was also adopted to predict the water temperature changes of the Lake Superior (USA-Canada border), which indicates that the physical model can be used to provide reliable spatiotemporal estimates of water temperature in complex lake systems [20]. These previous studies of water temperature demonstrate that hydrodynamic modeling has been used for a wide variety of lake systems. In addition, hydrodynamic models were also used in conjunction with remote sensing data to examine the water temperature in lakes $[12,21]$. For example, the remote sensing data present an opportunity to evaluate the spatial and temporal characteristics of water temperature from hydrodynamic models $[5,22]$. In general, hydrodynamic models are becoming more important for representing present or future conditions in order to account for the effects of climate change and human activity $[19,23,24]$.

Poyang Lake, the largest freshwater lake in China [25], is distinct from previous studies of lake water temperature in that it is a seasonally dynamic river-lake system that expands and contracts significantly, creating about $3000-\mathrm{km}^{2}$ floodplain areas [26]. The lake is a prominent example of a lake subjected to significant hydrological variations due to the combined influences of the catchment rivers and the Yangtze River [27,28], which results in the physical, chemical and biological changes [29-31]. Given the importance of these ecological parameters in the lake environment, more knowledge of the water temperature variations is a first step toward understanding how the water temperature may be potentially affected by climate change and/or anthropogenic activities and, in turn, how water temperature changes affect the lake ecosystem. Despite previous studies into the implications of water temperature for the water quality and associated functioning of Poyang Lake [32,33], spatial and temporal variations of water temperature are still highly unknown.

This study provides the first thermodynamics of the water temperature changes for Poyang Lake, a large floodplain lake, and it is also the first attempt to examine the spatiotemporal variability of water temperature in the lake. Our specific objectives are to: (1) analyze the quality of calibration of the 
hydrodynamic model using field measurements and remote sensing data; (2) investigate the spatial and temporal variability of lake water temperature using the simulation results; and (3) explore the influence of external conditions on water temperature using a sensitivity analysis approach.

\section{Materials and Methods}

\subsection{Study Area}

Poyang Lake $\left(28^{\circ} 4^{\prime}-29^{\circ} 46^{\prime} \mathrm{N}, 115^{\circ} 49^{\prime}-116^{\circ} 46^{\prime} \mathrm{E}\right)$ is located in northern Jiangxi Province near the southern bank of the middle reach of the Yangtze River (Figure 1) and is one of the few lakes in China that remains naturally connected to surrounding rivers [28]. The lake lies is in a humid, subtropical monsoon climate zone. Poyang Lake provides an important water resource, and the adjoining floodplains have been registered as an internationally-recognized wetland system [34]. It plays an important role in flood-mitigation storage and the protection of biodiversity, which serves industrial, urban, agricultural and environmental functions for 12.4 million residents [35]. The shorelines of Poyang Lake are tortuous, with a maximum length of $170 \mathrm{~km}$ and a mean width of $17 \mathrm{~km}$. The bottom morphology of the lake includes islands, shallow floodplains and deep flow channels (Figure 1), exhibiting complex topographical features [36]. The lake is characterized by lacustrine and riverine morphological processes that exhibit distinct seasonal variation [37]. In general, $85 \%$ of the lake is shallow with a water depth of less than $6 \mathrm{~m}$ during wet seasons [36]. The Lake appears to exhibit an isothermal mixed layer [38] for the entire waterbody for approximately $95 \%$ of the depth profiles (i.e., water temperature differences $<1{ }^{\circ} \mathrm{C}$ at 35 sites), and corresponding velocity differences are generally less than $0.2 \mathrm{~m} / \mathrm{s}$ [39], indicating that the vertical stratification of the lake can be neglected.

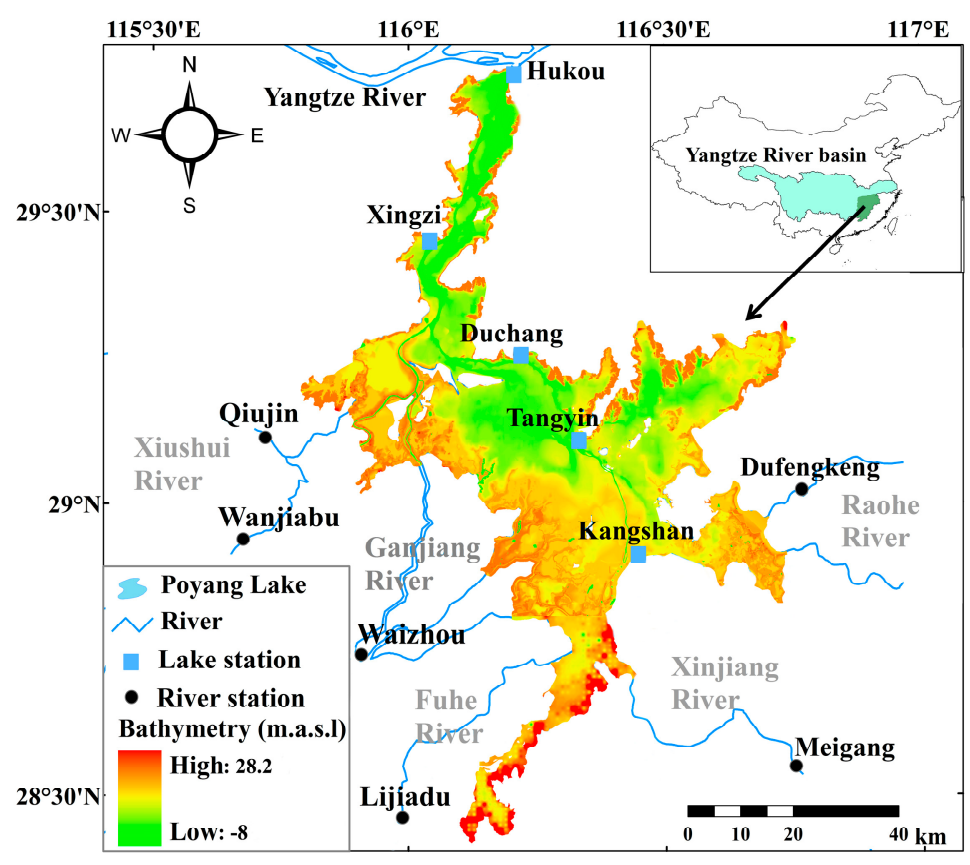

Figure 1. Map of the main rivers, distributed lake gauging stations (water level, water temperature and meteorological observations) within Poyang Lake and river gauging stations (river discharge and temperature observations) in its catchment.

Poyang Lake receives inflow predominantly (92\%) from five major rivers within its $1.62 \times 10^{5}-\mathrm{km}^{2}$ drainage catchment [25], including the Ganjiang, Fuhe, Xinjiang, Raohe and Xiushui Rivers (Figure 1). The remaining $8 \%$ is attributable to minor streams, rainfall to the lake surface and groundwater inflow [40]. Poyang Lake is connected to the Yangtze River through a relatively narrow and deep 
channel at its northern extremity Hukou (Figure 1). The hydrology of Poyang Lake varies seasonally under the combined effects of catchment river inflows and interactions with the Yangtze River [28,41]. These result in the water surface area varying from $<1000->3000 \mathrm{~km}^{2}$ each year in response largely to the water level fluctuations of 8-22 m [20]. Differences in water surface elevations can reach up to approximately $5 \mathrm{~m}$ in dry seasons, whereas the water surface is almost horizontal during flood seasons [42]. Poyang Lake exhibits spatially heterogeneous residence times that ranges from $<20->300$ days throughout the lake [43].

\subsection{Data Availability}

\subsubsection{Routine Observation Data}

Hourly meteorological conditions were observed at four gauging stations across the lake region: Xingzi, Duchang, Tangyin and Kangshan. Because none of those gauging stations provide measurements of all meteorological input parameters (i.e., air temperature, cloud cover, relative humidity, solar radiation, wind speed, wind direction, precipitation and evaporation), which are required to force the hydrodynamic model, parameters were retrieved from various stations (Table 1). Daily river discharge and temperature at the six downstream gauging stations of the five major rivers (Figure 1) were observed and used to represent the river components of catchment inflows. The gauging station of Hukou (Figure 1) was adopted to reflect the water level and temperature regimes adjacent to the Yangtze River. Within the lake, the water levels and temperatures obtained from the gauging stations of Xingzi, Duchang, Tangyin and Kangshan (Figure 1) were selected to represent spatial and temporal responses in lake conditions. All hydrometeorological data surrounding the lake are available for the period of one year (2015). These routine observation data were obtained from the Hydrological Bureau of Jiangxi Province and the Hydrological Bureau of the Yangtze River Water Resources Commission of the Ministry of Water Resources of China.

Table 1. Routine observation data used in this study.

\begin{tabular}{|c|c|c|}
\hline Parameter & Gauging Station & Purpose \\
\hline $\mathrm{AT}\left({ }^{\circ} \mathrm{C}\right)$ & Duchang, Kangshan & \multirow{8}{*}{ Meteorological conditions } \\
\hline $\mathrm{CC}(\%)$ & Xingzi & \\
\hline $\mathrm{RH}(\%)$ & Duchang & \\
\hline $\mathrm{SR}\left(\mathrm{W} / \mathrm{m}^{2}\right)$ & Xingzi & \\
\hline WS (m/s) & Duchang & \\
\hline WD (degree) & Duchang & \\
\hline $\mathrm{PCP}(\mathrm{mm})$ & Xingzi, Tangyin, Kangshan & \\
\hline $\mathrm{EA}(\mathrm{mm})$ & Xingzi, Tangyin, Kangshan & \\
\hline $\mathrm{RT}\left({ }^{\circ} \mathrm{C}\right)$ & Waizhou, Lijiadu, Meigang, Dufengkeng, Qiujin, Wanjiabu & \multirow{2}{*}{ Catchment effects } \\
\hline $\operatorname{DR}\left(\mathrm{m}^{3} / \mathrm{s}\right)$ & Waizhou, Lijiadu, Meigang, Dufengkeng, Qiujin, Wanjiabu & \\
\hline $\mathrm{LT}\left({ }^{\circ} \mathrm{C}\right)$ & Hukou, Xingzi, Duchang, Tangyin, Kangshan & \multirow{2}{*}{ Lake responses } \\
\hline $\mathrm{WL}(\mathrm{m})$ & Hukou, Xingzi, Duchang, Tangyin, Kangshan & \\
\hline
\end{tabular}

$\mathrm{AT}$, air temperature; $\mathrm{CC}$, cloud cover; $\mathrm{RH}$, relative humidity; $\mathrm{SR}$, solar radiation; WS, wind speed; WD, wind direction; PCP, precipitation; EA, evaporation; RT, water temperature of the catchment rivers; DR, discharge of the catchment rivers; $\mathrm{LT}$, water temperature of the lake; $\mathrm{WL}$, water level of the lake.

\subsubsection{Field Data and Remote Sensing Images}

The field measurements of water temperature in Poyang Lake were conducted for four typical periods on 15 January (winter), 10 April (spring), 15 July (summer) and 15 October (autumn) 2015, respectively, and the corresponding number of monitoring points was 22, 24, 73 and 12 (locations shown in Section 3.1). Therefore, a total of 131 spatial points of water temperature was measured $(0.5 \mathrm{~m}$ below the water surface) using a Hydrolab DataSonde 5 sensor (USA) across the lake. Because Poyang Lake is well mixed and large [39], we assumed that Poyang Lake does not experience large diurnal 
variations in water temperature, relative to that of air temperature. Therefore, a total of seven daytime and cloud-free Landsat 7 satellite images (USGS) (i.e., 4 January, 5 February, 13 February, 26 April, 9 September, 11 October and 19 October 2015) was extracted to further examine spatial variations of water surface temperature $(30 \mathrm{~m} \times 30 \mathrm{~m})$ in Poyang Lake and assess the hydrodynamic model. The methodology for the retrieval of water surface temperature is provided by Wilson and Rocha [44] and was applied similarly here. In brief, the approach involves the conversion of raw thermal data to at-satellite or top of atmosphere radiance values. In addition, the atmospheric correction parameters were determined from an online atmospheric correction tool developed for public website access by NASA [45]. Processing and analysis of the Landsat product were implemented in ENVI ${ }^{\circledR}$.

\subsection{Meteorological and Hydrological Conditions}

The meteorological and hydrological conditions directly affect dynamic processes of a lake, e.g., the water temperature. Figure 2 shows the hydrometeorological time series (daily means for the gauging stations) of Poyang Lake used in this study. The daily air temperature of the lake varied from $2.5^{\circ} \mathrm{C}-34{ }^{\circ} \mathrm{C}$ during the whole period (Figure 2a). The cloud cover has an important effect on the long wave radiation, with an average value of $33 \%$ (Figure $2 \mathrm{~b}$ ). The relative humidity that contributes to the heat exchange at an air-water interface varied from 31-99\% (Figure 3c). Solar radiation varied from $7.3 \mathrm{w} / \mathrm{m}^{2}-972 \mathrm{w} / \mathrm{m}^{2}$, which shows distinctly seasonal variations (Figure 3d). The wind dominantly blew from the E and SE directions, which corroborated the dominance of the subtropical monsoon climate, with an average speed of $2.2 \mathrm{~m} / \mathrm{s}$ (Figure 3e,f). The annual precipitation and evaporation reach up to 1900 and $850 \mathrm{~mm}$ /year, respectively (Figure 3g). It is apparent that the water temperatures from the lake and catchment rivers exhibit similar variation patterns to that of the air temperature (Figure 3h), indicating a close relationship between the two (i.e., correlation coefficient $=0.91$ ). The total river discharge from the catchment was 1.8 million $\mathrm{m}^{3} / \mathrm{s}$, which contributes to the water level dynamics of the lake (Figure 3i,j). It should be noted that the water levels for the autumn and winter seasons during 2015 are distinctly higher (up to $\sim 5 \mathrm{~m}$ ) than other years.
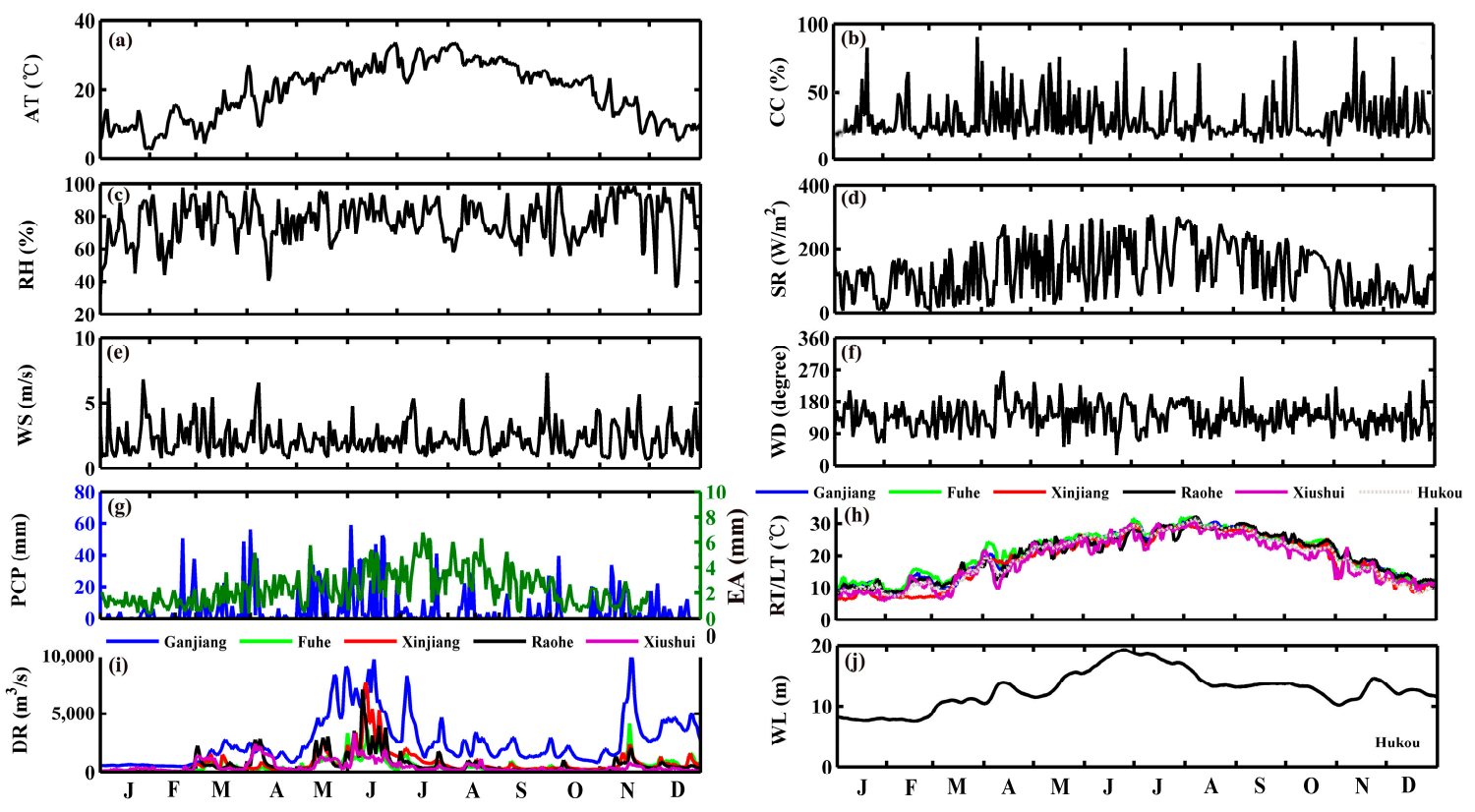

Figure 2. Daily time-series hydrometeorological conditions during 2015: (a) AT, air temperature; (b) CC, cloud cover; (c) RH, relative humidity; (d) SR, solar radiation; (e) WS, wind speed; (f) WD, wind direction; (g) PCP, precipitation and EA, evaporation; (h) RT, water temperature of the catchment rivers and LT, water temperature of the lake; (i) DR, river discharge from the catchment; and (j) WL, water level of the lake. The abbreviations of month are shown on the $x$-axis. 

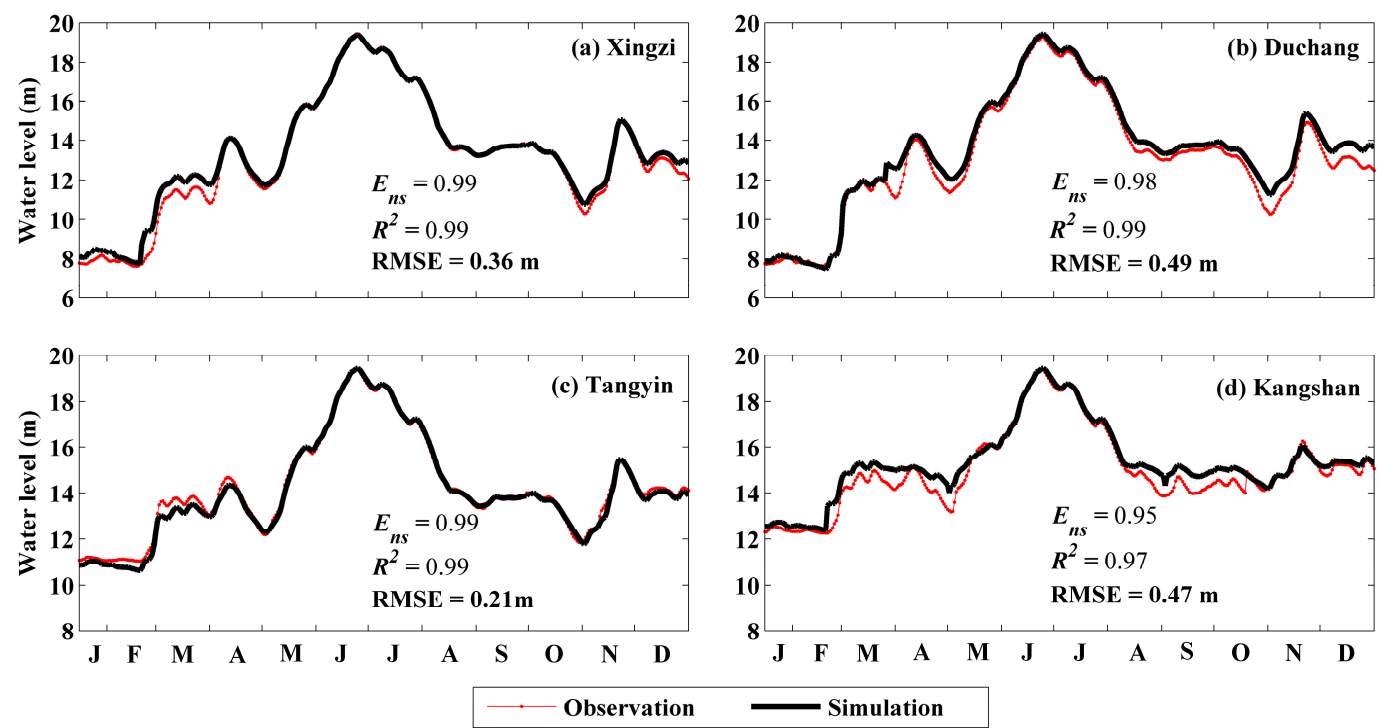

Figure 3. Comparison of modeled and observed water levels at (a) Xingzi, (b) Duchang, (c) Tangyin and (d) Kangshan gauging stations in Poyang Lake during 2015.

\subsection{Hydrodynamic Model Description and Setup}

The MIKE 21 used in this study is a 2D, depth-averaged, finite-volume flow model developed by the Danish Hydraulic Institute (DHI). MIKE 21 uses dynamically-coupled transport equations for water level, velocity and temperature simulations in waterbodies under the influence of major forcings (e.g., wind, river inputs, etc.) [46]. Li et al. [42] constructed a 2D hydrodynamic model of Poyang Lake using MIKE 21. The model domain covers the maximum historical flood inundation area of $3124 \mathrm{~km}^{2}$ and adopts a flexible unstructured mesh of variable cell sizes to capture the complex lake bathymetry (Figure 1). The element sizes vary from 70-1500 m, resulting in a total of 11,251 nodes and 20,450 triangular elements. Observed series of daily river discharge from five inflow rivers were set to varying in time and constant along the upstream boundary [42]. The observations of daily water levels at Hukou gauging station provide the lake's lower boundary condition for the hydrodynamic model (Figure 1). Spatially uniform, but time-varying precipitation and evaporation rates were input to the Poyang Lake hydrodynamic model as the atmospheric boundary condition [42]. Additionally, a spatially-uniform wind condition was also adopted in the hydrodynamic model. The time step is restricted to $5 \mathrm{~s}$ to keep the critical Courant-Friedrich-Lewy (CFL) number at 1.0 considering the model stability. The numerical option of wetting and drying in the hydrodynamic model was adopted and followed the rule $h_{\text {dry }}(0.005 \mathrm{~m})<h_{\text {flood }}(0.05 \mathrm{~m})<h_{\text {wet }}(0.1 \mathrm{~m})$. Model calibration and validation are described in detail by Li et al. [42]. The MIKE 21 model reproduces the dynamics of water levels, water surface areas and water flow patterns of the lake and has already been applied to various cases of Poyang Lake $[28,36,40,43,47]$. Other aspects of the model construction can be found in the above references, and therefore, only a brief description is given in this section.

In the current study, the water temperature simulation is conducted by using the updated hydrometeorological data during 2015 (see Figure 2), which were imposed on the previous statuses of the MIKE 21 hydrodynamic model of Poyang Lake [42]. The temperature is invoked from the specification of the density since baroclinic density (i.e., density depends on temperature) is selected. The meteorological input data included daily air temperature, cloud cover, relative humidity, solar radiation, wind speed and direction, precipitation and evaporation. In addition, observed daily hydrological data of the catchment rivers (discharge and temperatures) and lake outlet (Hukou water levels and temperatures) were used to provide the boundary conditions for the MIKE 21 model. 


\subsection{Model Calibration and Skill Assessment}

The calibration of the model in this study was executed in several steps, where the variable model parameters were improved gradually. For each step, many simulations were implemented by varying only one parameter in a reasonable range while holding the other parameters constant. Each simulation result was evaluated separately by comparing with the measured lake water levels and water temperatures. After each step, the best simulation results was used as a new basis to perform the next set of calibration runs. This procedure was repeated until the comparison reached a close agreement between the model results and field observations. The final specifications of the MIKE 21 model parameters after the calibration for Poyang Lake are presented in Table 2. The values and settings were also used for the sensitivity analysis of hydrodynamic simulations (see the next section).

Table 2. Key parameters used in the MIKE 21 hydrodynamic model.

\begin{tabular}{ccc}
\hline Description & Value and Unit & Reference \\
\hline Manning's roughness coefficient & $0.02-0.03\left(\mathrm{~s} / \mathrm{m}^{1 / 3}\right)$ & {$[42]$} \\
Smagorinsky factor for eddy viscosity & $0.28(-)$ & {$[42]$} \\
Critical wind speed & $3.0(\mathrm{~m} / \mathrm{s})$ & {$[19]$} \\
Light extinction coefficient & $1.0(1 / \mathrm{m})$ & {$[19]$} \\
Constant in Dalton's law & $0.5(-)$ & {$[48]$} \\
Wind coefficient in Dalton's law & $0.9(-)$ & {$[48]$} \\
Exchange coefficient in Beer's law & $0.8(-)$ & {$[46]$} \\
Transfer coefficient for healing and cooling & $0.005(-)$ & {$[49]$} \\
\hline
\end{tabular}

Several different statistical methods were selected to investigate the quality of the model's calibration results due to their frequent usage in modelling studies. In our study, we compared modeled and measured data by using Nash-Sutcliffe efficiency coefficient $\left(E_{n s}\right)$, determination coefficient $\left(R^{2}\right)$ and root mean square error (RMSE) [40]. The ideal value for $E_{n s}$ and $R^{2}$ is 1 , and the ideal value for $R M S E$ is $0 \mathrm{~m}$ or $0{ }^{\circ} \mathrm{C}$.

\subsection{Sensitivity Analysis Approach}

After the model calibration, the sensitivity analysis of MIKE 21 to changes in meteorological conditions and the river water temperature was performed in the same way as the calibration process. In brief, the input conditions were modified separately by adding offset values to the observed daily data or multiplying them by a factor. The method of addition and multiplication depended on the range of values of the respective condition. In this study, the methodology for sensitivity analysis of water temperature is similar to the previous study by Bueche and Vetter [19].

Table 3 shows the modifications of the input conditions applied in the current sensitivity analysis. Because air temperature (AT) and water temperature of the catchment rivers (RT) values usually range from positive to negative, they cannot be multiplied to achieve only an increase or a decrease in one modification process. Hence, these input conditions were added to positive and negative offsets, respectively. Modifications of cloud cover (CC) and RH were carried out by multiplication by a factor. The resulting values $>100 \%$ were set back to $100 \%$ to keep all values in the theoretical range (see Table 3). Zero is a common value for the input conditions wind speed (WS) (daily mean), precipitation (PCP) (daily sums) and evaporation (EA) (daily sums). Therefore, modifications of the observed values of these conditions were obtained by multiplication; the value of 0 still occurs in the modified data. Additionally, the maximum value and the associated total value ranges of the inputted data also change. Multiplying solar radiation (SR) values by any factor would modify the higher values more than the lower ones and change the total value range of the data. Therefore, the modifications of SR were also carried out by addition, and data of SR were added to reasonable values that represent deviations of $2 \%$ and $5 \%$ of the mean of the value range of the observed data (Table 3 ). 
Table 3. Modifications of the input conditions applied in the sensitivity analysis.

\begin{tabular}{ccccccc}
\hline \multirow{2}{*}{ Parameter } & \multicolumn{3}{c}{ Variations of Parameter } & \multicolumn{2}{c}{ Theoretical Range } \\
\cline { 2 - 6 } & \multicolumn{2}{c}{ Increase } & \multicolumn{2}{c}{ Decrease } & min & max \\
\hline $\mathrm{AT}\left({ }^{\circ} \mathrm{C}\right)$ & +1.0 & +2.0 & -1.0 & -2.0 & $-\infty$ & $+\infty$ \\
$\mathrm{CC}(\%)$ & $\times 1.05$ & $\times 1.10$ & $\times 0.95$ & $\times 0.90$ & 0 & 100 \\
$\mathrm{RH}(\%)$ & $\times 1.05$ & $\times 1.10$ & $\times 0.95$ & $\times 0.90$ & 0 & 100 \\
$\mathrm{SR}\left(\mathrm{W} / \mathrm{m}^{2}\right)$ & +19.44 & +48.6 & -19.44 & -48.6 & 0 & $+\infty$ \\
$\mathrm{WS}(\mathrm{m} / \mathrm{s})$ & $\times 1.2$ & $\times 1.5$ & $\times 0.80$ & $\times 0.50$ & 0 & $+\infty$ \\
$\mathrm{PCP}(\mathrm{mm})$ & $\times 1.05$ & $\times 1.10$ & $\times 0.95$ & $\times 0.90$ & 0 & $+\infty$ \\
$\mathrm{EA}(\mathrm{mm})$ & $\times 1.05$ & $\times 1.10$ & $\times 0.95$ & $\times 0.90$ & 0 & $+\infty$ \\
$\mathrm{RT}\left({ }^{\circ} \mathrm{C}\right)$ & +1.0 & +2.0 & -1.0 & -2.0 & $-\infty$ & $+\infty$ \\
\hline
\end{tabular}

The theoretical ranges of values are defined by the potential maximum and minimum value. AT, air temperature; $\mathrm{CC}$, cloud cover; $\mathrm{RH}$, relative humidity; SR, solar radiation; WS, wind speed; PCP, precipitation; EA, evaporation; $\mathrm{RT}$, water temperature of the catchment rivers.

In this study, the sensitivity of each input condition was analyzed using the formulation as follows:

$$
\text { Water temperature change }\left({ }^{\circ} \mathrm{C}\right)=\frac{1}{N} \sum_{i=1}^{N} \mid \text { Output }- \text { Baseline } \mid
$$

In Equation (4), $N$ denotes the number of variations for which the sensitivity is obtained (i.e., $N=4$; Table 3), constructed with baseline results and corresponding simulation outputs. Consequently, the mean water temperature changes for each computational cell of the MIKE 21 model were obtained to show the spatial responses of water temperatures across Poyang Lake.

\section{Results}

\subsection{Hydrodynamic Model Calibration}

A comparison of modeled and observed water levels at four lake gauging stations during 2015 is depicted in Figure 3. The $E_{n s}$ of Xingzi, Duchang, Tangyin and Kangshan gauging stations varies from 0.95-0.99, and $R^{2}$ ranges from 0.97-0.99. The RMSE values of all stations are less than $0.5 \mathrm{~m}$, suggesting a close agreement between the model and field observations. The hydrodynamic model predicts well the observed daily water temperatures at four gauging stations, producing $R^{2}, E_{n s}$ and RMSE in ranges of $0.94-0.99,0.92-0.96$ and $1.5-1.9^{\circ} \mathrm{C}$, respectively (Figure 4). That is, the spatial and temporal characteristics of water temperatures are satisfactorily reproduced in the model results. However, there is at least one intense deviation of the simulations from the observations at some gauging stations (e.g., Duchang and Tangyin), and these deviations mostly occur in the summer seasons $\left(>2{ }^{\circ} \mathrm{C}\right)$. This implies that the lake water temperature is likely to exhibit more sensitive and complex responses than the water level to the external forcings. Overall, the visual inspection and statistical evaluation (i.e., $R^{2}, E_{n s}$ and $R M S E$ ) demonstrate that the current model has the ability to capture seasonal variations of the thermodynamic and hydrodynamic characteristics of Poyang Lake.

Figure 5 shows the water temperature differences between modeled and measured values on four dates in 2015. Differences between the two are both positive (red circles) and negative (black circles), but are generally less than $1.0^{\circ} \mathrm{C}$ (i.e., $72 \%$ of the 131 points), demonstrating that the simulation results show satisfactory agreement with the measurements. In addition, the absolute values of water temperature difference are less than $1.7^{\circ} \mathrm{C}$ for the four dates (Figure 5), indicating that no extreme variations were simulated, and the model represents the conditions reasonably. It should be noted that the model produces a large number of underestimated water temperatures (i.e., $60 \%$ of the 131 points; black circles), as reflected in $R^{2}$ values in the range of $0.65-0.81$ (Figure 5). 

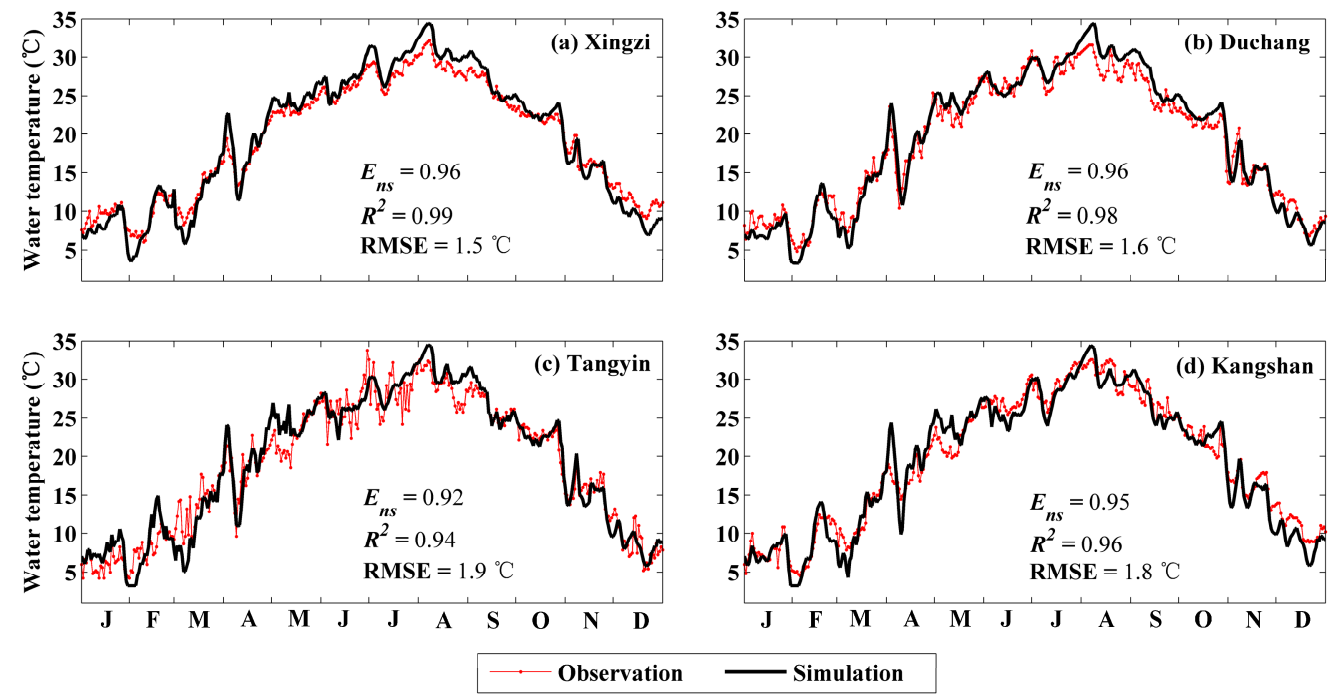

Figure 4. Comparison of modeled and observed water temperatures at (a) Xingzi, (b) Duchang, (c) Tangyin and (d) Kangshan gauging stations in Poyang Lake during 2015.

A spatially-resolved comparison of surface water temperature estimated in Poyang Lake using Landsat 7 data and MIKE 21 simulated temperature is shown in Figure 6. A visual interpretation of Landsat and simulation (30-m resolution) indicates that the pattern and magnitude of the water temperature are simulated well for different dates. That is, MIKE 21 results agree with the spatial distribution of temperatures derived by Landsat data. Compared to the Landsat data, the simulated water temperature in the main flow channels across the lake length is better reproduced than that shown in the western floodplain areas. The reason can be attributed to the influence of the complex hydrodynamic field in the lake, which likely exerts more influence on the prediction of floodplains than main flow channels [36,42]. Additionally, the simulated water temperature in some lake center regions was not in agreement with that shown by Landsat (e.g., 26 April and 11 October), with an average temperature difference up to approximately $3{ }^{\circ} \mathrm{C}$ (Figure $\left.6 \mathrm{~d}, \mathrm{f}\right)$. The statistical results shown in Table 4 indicate that the simulated and Landsat values exhibit similar spatial characteristics and good correlations (i.e., Adj- $R^{2}>0.80$ ). Overall, these results demonstrate that the model simulated spatial variation in lake water temperature reasonably well (Figure 6 and Table 4), building confidence in the applicability of the hydrodynamic model.

Table 4. Assessment of spatial water temperature derived from the simulated and Landsat data. Adj- $R^{2}$ represents goodness-of-fit statistics using all the spatial data.

\begin{tabular}{cccccccc}
\hline Date & \multicolumn{3}{c}{ Simulation } & \multicolumn{3}{c}{ Landsat } & \multirow{2}{*}{ Adj- $\boldsymbol{R}^{\mathbf{2}}$} \\
\cline { 1 - 7 } & Average & Min & Max & Average & Min & Max & \\
\hline 4 January 2015 & 7.1 & 6.8 & 9.8 & 7.5 & 5.8 & 8.9 & 0.92 \\
5 February 2015 & 6.5 & 6.4 & 7.5 & 6.7 & 6.2 & 7.8 & 0.91 \\
13 February 2015 & 10.7 & 6.7 & 16.3 & 10.7 & 7.4 & 14.3 & 0.92 \\
26 April 2015 & 21.3 & 16.3 & 23.4 & 19.8 & 18.9 & 23.3 & 0.81 \\
9 September 2015 & 28.2 & 21.8 & 31.9 & 26.5 & 24.7 & 30.9 & 0.80 \\
11 October 2015 & 22.1 & 18.2 & 31.6 & 24.4 & 18.2 & 33.9 & 0.85 \\
19 October 2015 & 21.5 & 15.8 & 21.0 & 22.8 & 17.3 & 23.2 & 0.87 \\
\hline
\end{tabular}



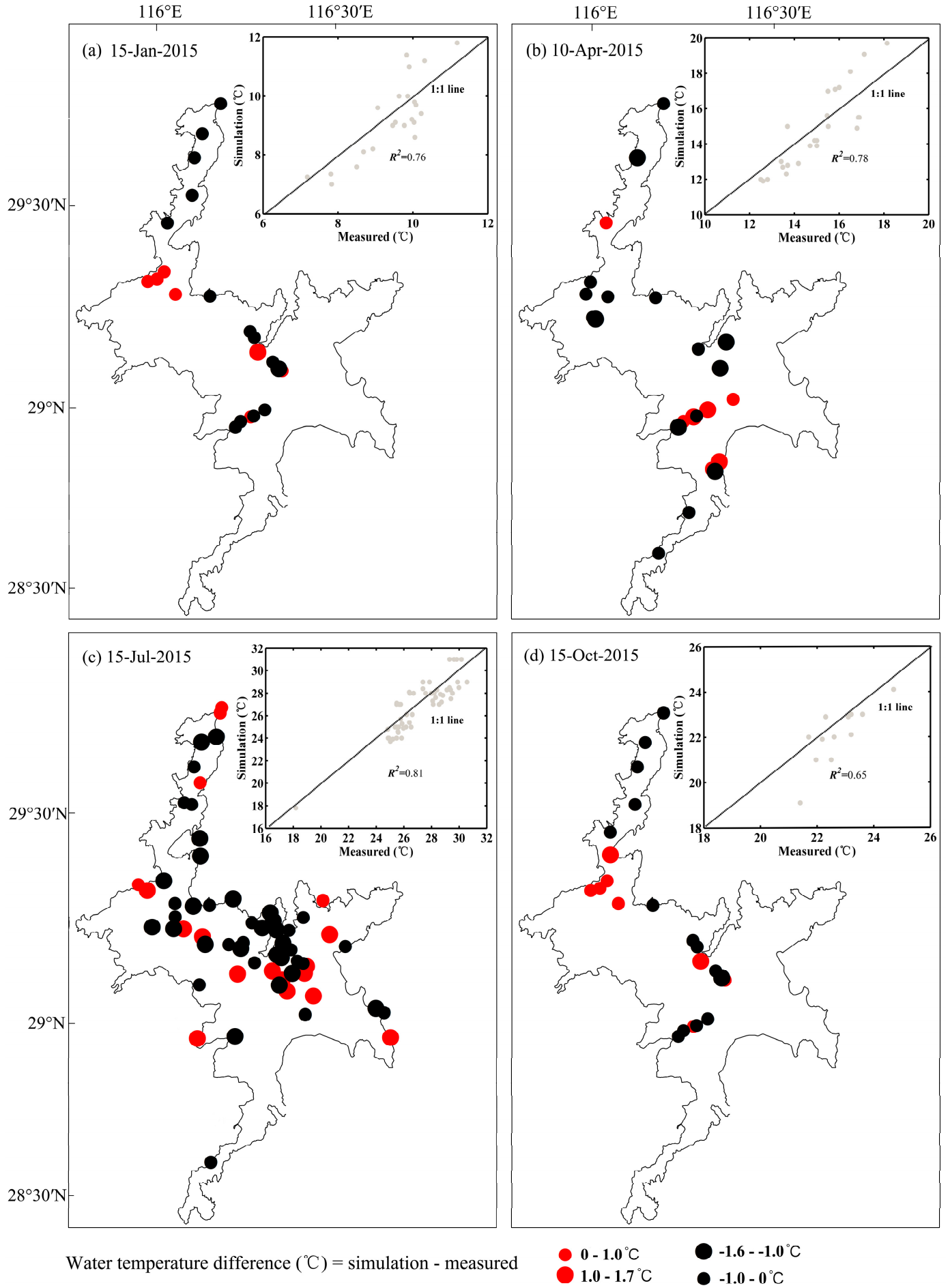

Figure 5. Differences between modeled and measured water temperatures at the 131 points (the circles) in Poyang Lake on (a) 15 January 2015, (b) 10 April 2015, (c) 15 July 2015 and (d) 15 October 2015. The red circles indicate that the simulations are higher than the measurements, and the black circles indicate that the simulations are lower than the measurements. The inserts represent the relationship between the simulations and measurements using liner fitting curves. 

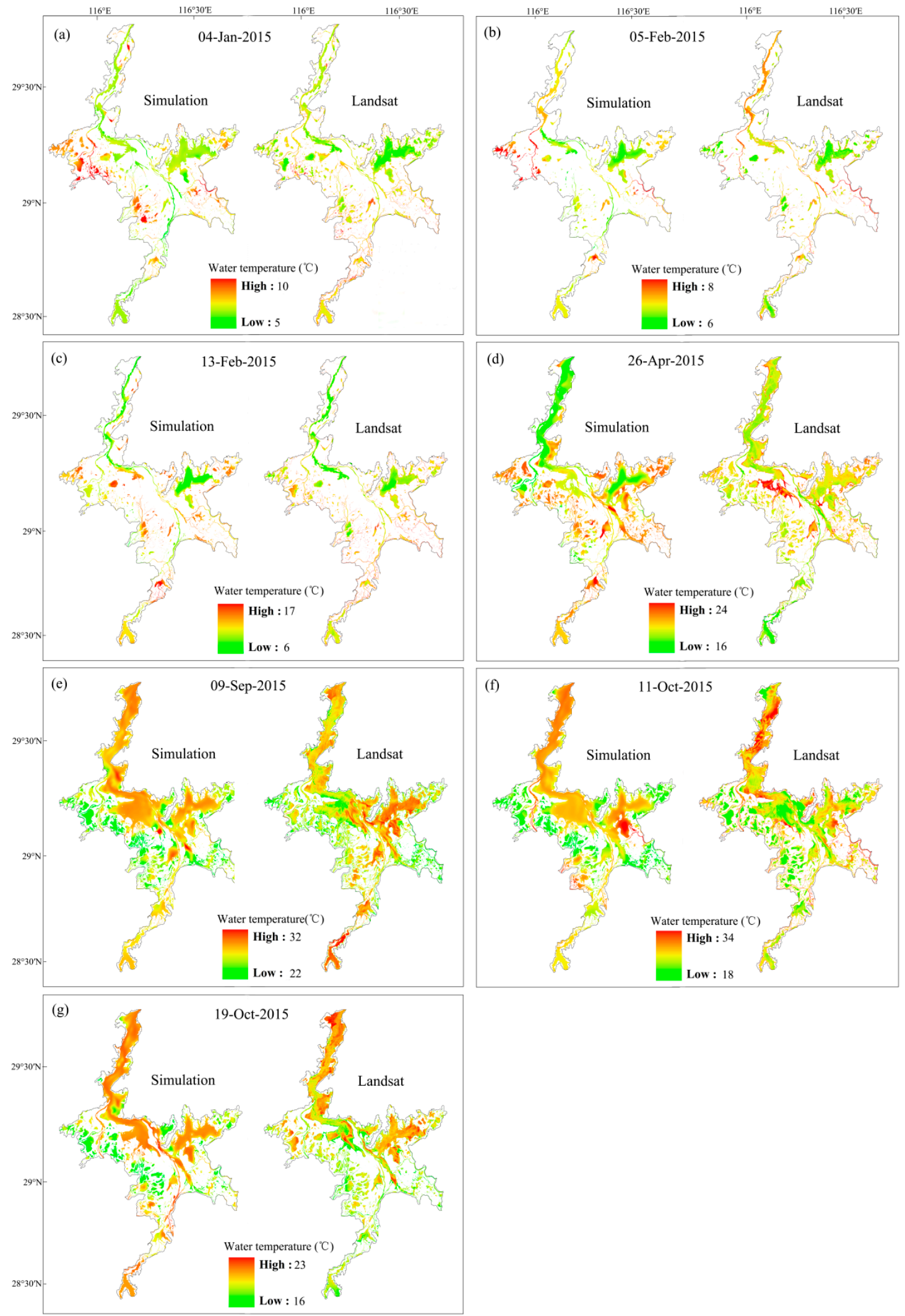

Figure 6. Comparison of simulated water temperature and Landsat-derived water surface temperature in Poyang Lake for seven dates in 2015. The white area in (a-g) within the lake denotes dry land. 


\subsection{Spatial and Temporal Variability of Lake Water Temperature}

Mean monthly maps of the simulated water temperature during 2015 are presented in Figure 7, as well as the lake-averaged descriptive statistics (mean, minimum and maximum). The minimum water temperature of Poyang Lake occurs in January $\left(3.2{ }^{\circ} \mathrm{C}\right)$, whereas the maximum values are observed in August $\left(33.8^{\circ} \mathrm{C}\right)$. The mean monthly lake-averaged values of the lake water temperature vary from $7{ }^{\circ} \mathrm{C}$ in January to $31.2^{\circ} \mathrm{C}$ in August. Generally, monthly variations of Poyang Lake water temperature increase from January-August and then decrease to about $8.8^{\circ} \mathrm{C}$ in December, indicating a distinctly temporal variability of the water temperature. It can be found that some areas in the western part of the lake do not exhibit high temperature until May $\left(\sim 15^{\circ} \mathrm{C}\right)$ and differ from the other region of the lake, due to water flow extended from the lake main channels to the adjacent floodplains [42]. The water temperature difference within the lake peaks in April, with the largest spatial difference being by up to $\sim 20^{\circ} \mathrm{C}$, while the spatial difference is minimized in July $\left(\sim 4{ }^{\circ} \mathrm{C}\right)$. However, the large spatial variability of water temperature within the lake occurs in summer months, whereas less variability in the lake water temperature is found in January and February. Additionally, the high spatial variability in summer months also reflects the strong seasonal warming in the floodplains, relative to weaker heating in the deep parts of the lake's main flow channels (Figure 7), as expected.

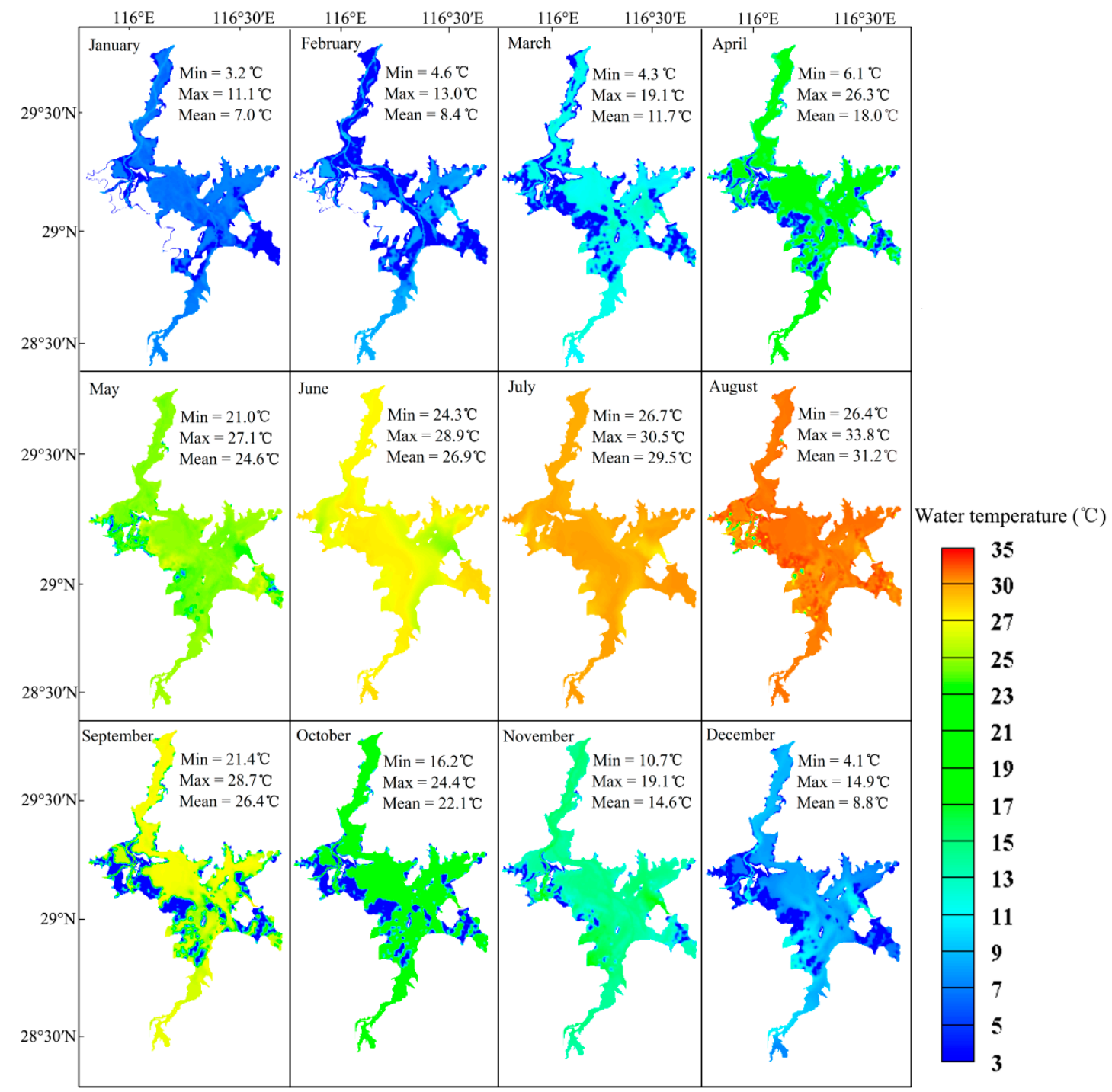

Figure 7. Mean monthly distributions of simulated water temperature for Poyang Lake during 2015. The white area within the lake denotes dry land in the floodplains during low water level months. 
Seasonal variations of Poyang Lake water temperature in the period of 2015 are illustrated in Figure 8. The mean seasonal water temperatures vary substantially from $29.1{ }^{\circ} \mathrm{C}$ in summer to $7.7^{\circ} \mathrm{C}$ in winter. In addition, the water temperature shows high spatial variability and varies quite distinctly within the lake. For different seasons, the high water temperature is almost evenly distributed in some shallow floodplain areas throughout the lake, and the relatively low water temperature is observed in the lake's main flow channels and river inlets adjacent to the lake shoreline, particularly in the summer season (Figure 8). That is, the water temperature generally decreases from the shallow floodplains to the lake's main flow channels at the seasonal scale, partly attributable to the influence of the changes in lake water depth. Although the degree of spatial and temporal variability differed considerably between seasons, the water temperature distributions in Poyang Lake exhibit similar characteristics in terms of the spatial pattern. Additionally, the water temperature shows relatively complex distributions across Poyang Lake. In general, three distinct thermal zones can be recognized along the entire lake: the shoreline (water depth $<\sim 1 \mathrm{~m}$ ), the floodplains (water depth $<\sim 5 \mathrm{~m}$ ) and the main flow channels (water depth $>\sim 8 \mathrm{~m}$ ).

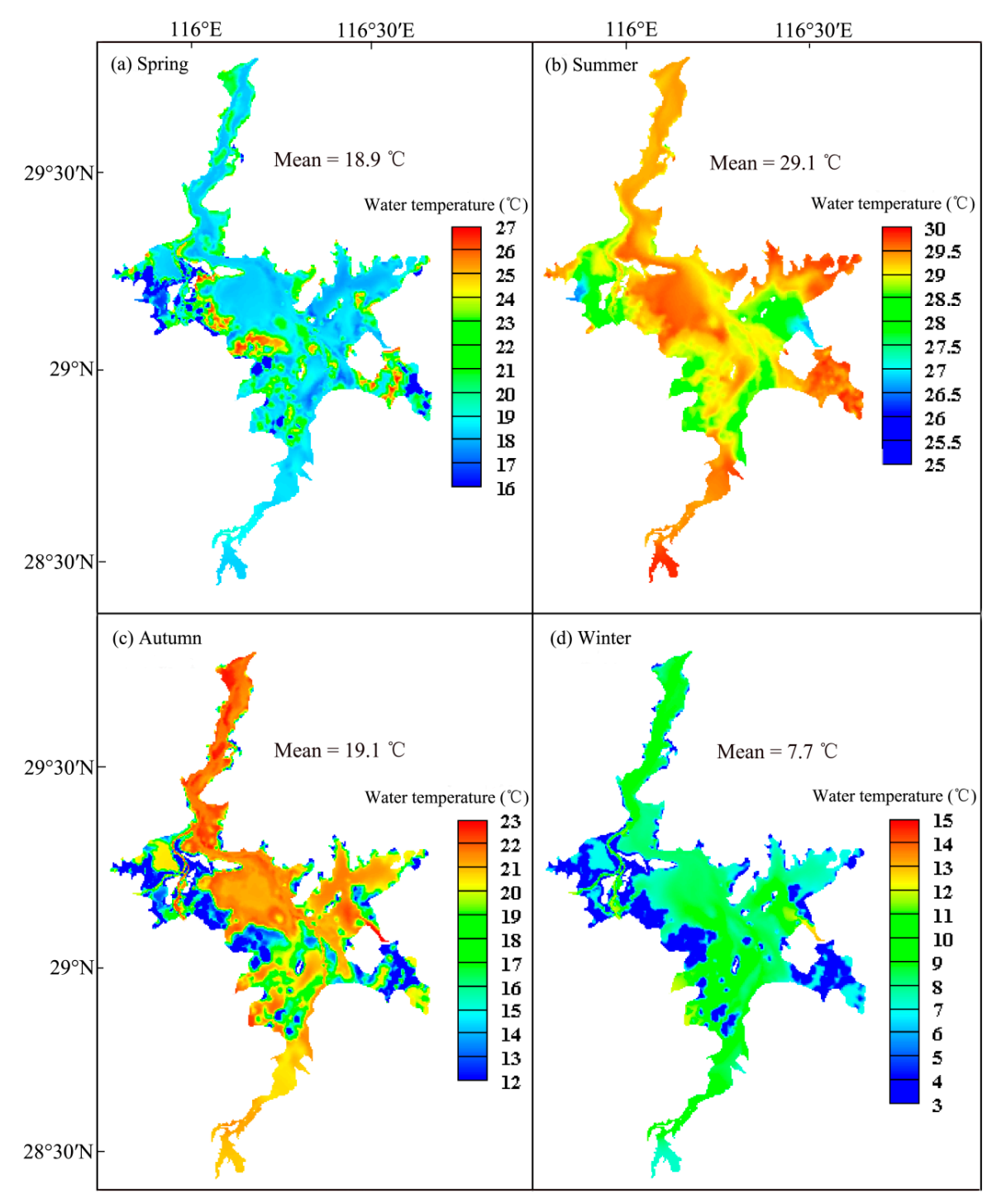

Figure 8. Seasonal variations of simulated water temperature within Poyang Lake for (a) spring (averaged over March, April and May), (b) summer (June, July and August), (c) autumn (September, October and November) and (d) winter (December, January and February). The white area within the lake denotes dry land in the floodplains. 


\subsection{Sensitivity Analysis}

Figure 9 shows the spatial changes in water temperature of Poyang Lake, which are the result of modifications in the respective input parameters (Table 3). Sensitivity analysis indicates that the modifications of input conditions exhibit influences on the model results with variable specifications. That is, the resulting changes in water temperature can occur at different lake regions to varying degrees. A constant variation in AT of $1{ }^{\circ} \mathrm{C}$ and $2{ }^{\circ} \mathrm{C}$ (Figure 9a) affects distinct higher water temperatures in the range of $\sim 0.1{ }^{\circ} \mathrm{C}-\sim 1.5^{\circ} \mathrm{C}$ for the entire lake. The strongest warming effect takes place in the shallow regions adjacent to the shoreline, with a maximum of about $1.5^{\circ} \mathrm{C}$. Other regions of the lake experience a significantly increased temperature gradient from the catchment river inlets $\left(<0.5^{\circ} \mathrm{C}\right)$ to the central regions (up to $1.2^{\circ} \mathrm{C}$ ). It is expected that the water temperature exhibits obviously spatial changes across the lake. However, the water temperature in the lake's main flow channels $\left(<1^{\circ} \mathrm{C}\right)$ is relatively lower compared to the other shallow regions, which is an expected outcome given that the flow structure of the lake may exert substantial influences on the water temperature.

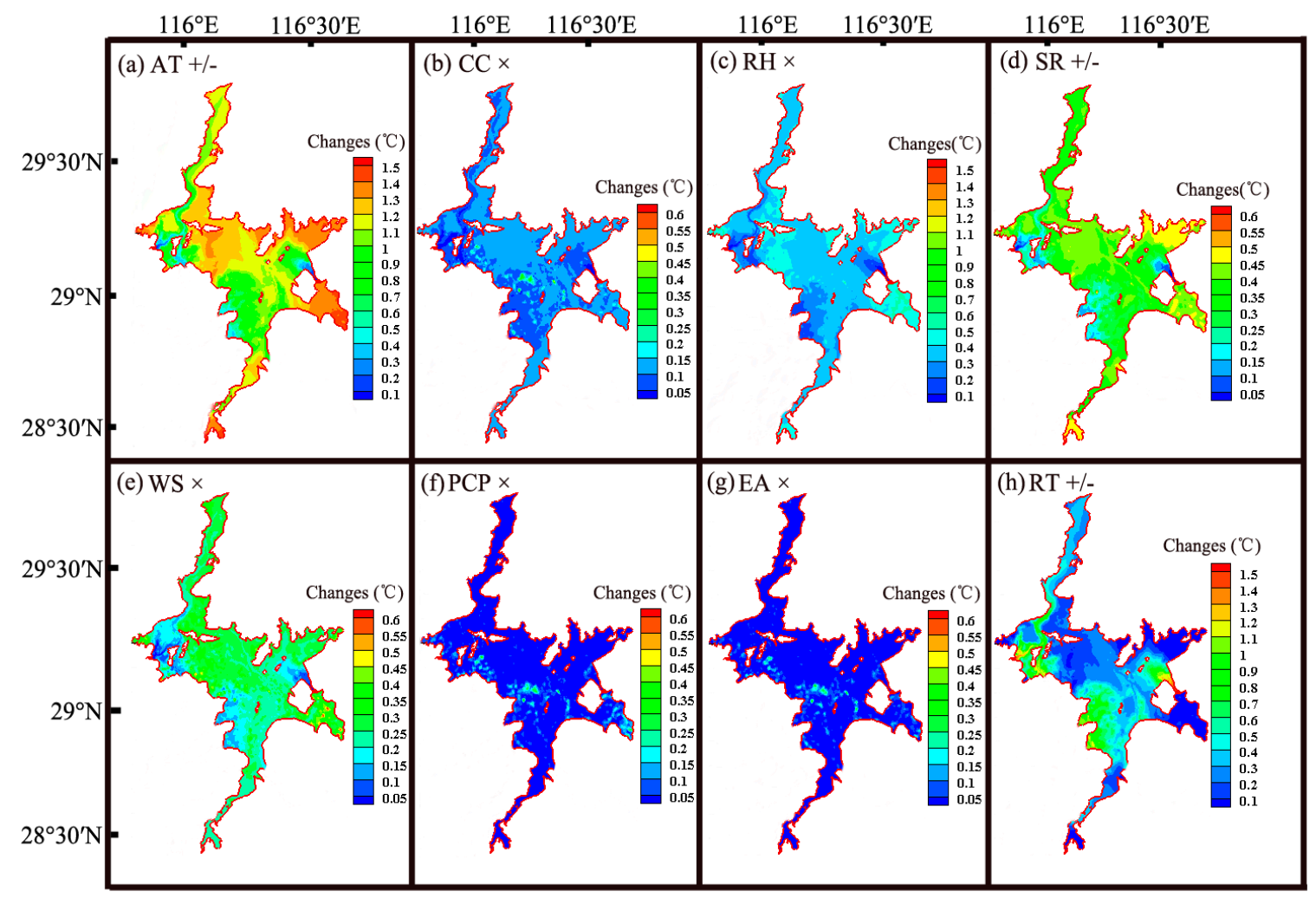

Figure 9. Sensitivity results of water temperature changes for Poyang Lake. The symbol $(+,-$ and $\times$ ) represents the increase and/or decrease scenarios. All values are obtained according to Equation (1). AT, air temperature; CC, cloud cover; $\mathrm{RH}$, relative humidity; SR, solar radiation; WS, wind speed; $\mathrm{PCP}$, precipitation; EA, evaporation; $\mathrm{RT}$, water temperature of the catchment rivers. The eight graphs represent average changes after the modifications of (a) AT, (b) CC, (c) RH, (d) SR, (e) WS, (f) PCP, (g) EA and (h) RT.

The hydrodynamic model simulates slight changes in water temperature when CC is modified by a multiplication factor (Figure 9b). The range of the water temperature variation is from $\sim 0.1^{\circ} \mathrm{C}-\sim 0.6^{\circ} \mathrm{C}$ across the lake. The water temperature distribution clearly shows a weak gradient $\left(\sim 0.1^{\circ} \mathrm{C}-\sim 0.2^{\circ} \mathrm{C}\right)$, with the minimum temperature close to the catchment river inlets. Modifications in $\mathrm{RH}$ cause similar characteristics of the spatial variations for CC, as shown in Figure 9c. However, the water temperature increases in Figure $9 \mathrm{c}$ are more pronounced. Water temperature are subjected to relatively large changes with a value of approximately $0.5^{\circ} \mathrm{C}$ for most regions. 
The variation in SR input values (Table 3) effects a very obvious increase in water temperature throughout the lake (Figure 9d). The large variation of $\sim 0.6^{\circ} \mathrm{C}$ in the eastern region and the small variation of $\sim 0.1^{\circ} \mathrm{C}$ in the river inlets can be observed, whereas the spatial change in water temperature is more or less uniform $\left(\sim 0.4{ }^{\circ} \mathrm{C}\right)$ in the main body of the lake. The result for the modified WS values also effects an increase in water temperature by up to $0.6{ }^{\circ} \mathrm{C}$ (Figure 9e), which is similar to the characteristics of the spatial changes in SR. Compared to the influences of the meteorological variables like SR and WS, modifications in PCP and EA cause only slight changes in water temperature, as shown in Figures $8 \mathrm{f}$ and $9 \mathrm{~g}$. It is notable that the increase in water temperature is almost less than $0.1{ }^{\circ} \mathrm{C}$ for most of the lake areas, which indicates that the water temperature is insensitive to PCP and EA.

The influence on the simulations resulting from changing the water temperature of the catchment rivers (i.e., $\mathrm{RT}= \pm 1^{\circ} \mathrm{C}$ and $\pm 2{ }^{\circ} \mathrm{C}$ ) is shown in Figure $9 \mathrm{~h}$. The water temperature exhibits a gradual decrease from the river inlets and adjacent main flow channels $\left(\sim 0.8^{\circ} \mathrm{C}-\sim 1.5^{\circ} \mathrm{C}\right)$ to the main body of the lake $\left(\sim 0.1^{\circ} \mathrm{C}-\sim 0.8^{\circ} \mathrm{C}\right)$. Generally, the variation of the water temperature shows a large spatial variability $\left(\sim 0.1^{\circ} \mathrm{C}-\sim 1.5^{\circ} \mathrm{C}\right)$ across the lake, with the highest value $\left(\sim 1.5^{\circ} \mathrm{C}\right)$ in the river inlets and the lowest value in the eastern lake regions $\left(0.1^{\circ} \mathrm{C}\right)$. In addition, water temperatures react with relatively weak responses (i.e., $<0.3^{\circ} \mathrm{C}$ ) in the shallow floodplains of the lake midstream. The river input from the catchment has a strong effect on the spatial changes of water temperature within the lake, as expected, but nonetheless attenuates with distance from the river inlets.

\section{Discussion}

This study analyzes the results of the calibration of the 2D hydrodynamic model MIKE 21 for Poyang Lake. It is acknowledged that deviations remained between model results, field measurements and remote sensing data. In general, the uncertainties are mainly attributed to the following sources: (1) errors in the field measurements, (2) too few validation runs with multivariate model parameter combinations [19] and (3) limited meteorological data for model forcing [50]. Considering these multiple sources of errors, the present estimation of the simulation results (Figures 3-6) attests to the satisfactory representation of the observed conditions within Poyang Lake. As discussed previously, the hydrodynamic model simulates the depth-averaged water temperature of Poyang Lake, whereas the in situ measurements are usually collected at specific depths (e.g., $0.5 \mathrm{~m}$ below the water surface) in the water column. Additionally, the remote sensing approach can only obtain the skin temperature of the water column [12]. Hence, a consistent comparison between model simulations and observations may reduce the deviations by using some adjustment techniques (e.g., data assimilation) [12]. Another limitation is the $2 \mathrm{D}$ depth-averaged temperature in the lake applies to conditions where the water column is not stratified. It is reasonable to expect some amount of water temperature stratification during high water-level seasons. Although previous work has concluded that Poyang Lake is mixed well in most areas (i.e., $85 \%$ of the lake) throughout different seasons [36,39], the depth-averaged approach may not be quite adequate for the prediction of water temperature in some potentially stratified regions. As such, the extension of a 3D representation in the lake is useful to account for the vertical distribution in the water temperature. Indeed, given that the unique characteristics of Poyang Lake such as large area, dynamic change in floodplains, heterogeneous topography and disconnection between lake segments during certain periods of the year [51], the current MIKE 21 model is promising to simulate the hydrodynamic and temperature conditions of the lake in response to multiple forcings to support decision/policy makers for the sustainable management of the lake environment.

Primary factors that affect the lake water temperature include meteorological conditions, topography, river inflows and outflows [4,19]. For Poyang Lake, regression analysis indicates that, in a general sense, air temperature, solar radiation and inflow temperature appear to have more significantly influences $(p<0.05)$ on water temperature than other factors (see Figure 10$)$, in agreement with the findings of the hydrodynamic investigation as shown in Figure 9. In the current study, although varying only one input parameter is not sufficient to represent the conditions of changing climate and hydrology, this modification approach is suitable to investigate the sensitivity of the 
hydrodynamic model to changes in external forcings, because the direct influence of each input parameter can be investigated separately [19]. In some lakes, topography plays an important role in inducing temperature gradients between deep and shallow areas $[5,20]$. In Poyang Lake, for example, there are extensive shallow floodplain areas and deep flow channels that vary in temperature from the main body of the lake. Therefore, the topography and associated water depth changes may partly influence the spatial pattern of water temperature within Poyang Lake [42]. However, a more general analysis of topography effects is beyond the scope of the current study.

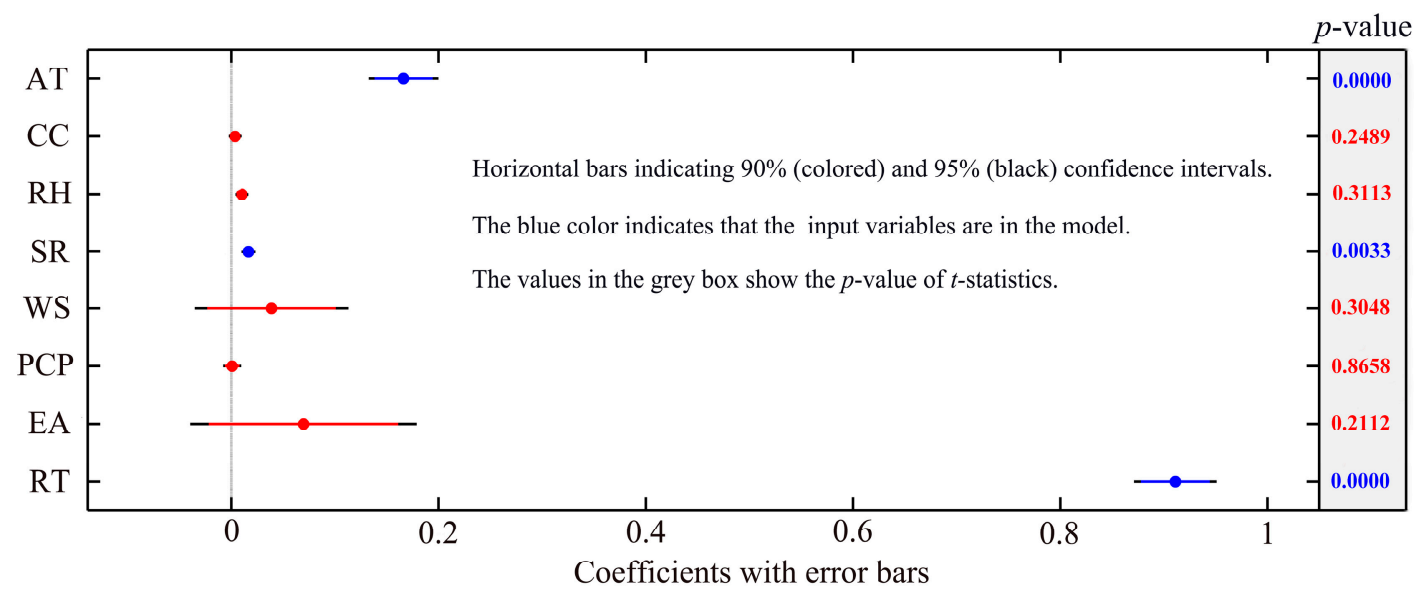

Figure 10. Stepwise regression analysis for the influences of input conditions on the average water temperature of Poyang Lake. AT, air temperature; CC, cloud cover; RH, relative humidity; SR, solar radiation; WS, wind speed; $\mathrm{PCP}$, precipitation; EA, evaporation; RT, water temperature of the catchment rivers.

It is anticipated that the proposed hydraulic project, the Poyang Lake Dam, will be designed across the downstream channel that links Poyang Lake with the Yangtze River [52]. It is noteworthy that the hydrological and hydrodynamic processes within the lake will be disturbed [43], and the water temperature distributions throughout the lake will also be affected. In this case, these possible changes are more likely to result in considerable impacts on the water quality and ecosystem of the already environmentally-degraded Poyang Lake and adversely affect the significant population that is dependent on the lake's water resources [32]. Consequently, further research is needed to investigate the interactions between the lake water temperature and the density distribution across the lake. In addition, the present work provides a basis to further couple some thermo-dynamic and chemo-dynamic models for investigating the future ecological conditions of Poyang Lake.

\section{Conclusions}

The 2D hydrodynamic model MIKE 21 coupled with a transport model is the first to interrogate the spatial and temporal variability of water temperature within a large floodplain lake (Poyang Lake, China). The influence of hydrometeorological conditions on the water temperature of Poyang Lake was examined using hydrodynamic modelling. The model is validated with extensive field measurements and remote sensing data during 2015. The results indicate that the hydrodynamic model reproduced reasonably well the spatial lake water level and water temperature variations within Poyang Lake.

The simulation results provide insights into the spatial and temporal variability in the water temperature of the lake. Results show that the water temperature increases from January-August and decreases to about $8.8^{\circ} \mathrm{C}$ in December. The mean seasonal water temperatures vary substantially from $29.1{ }^{\circ} \mathrm{C}$ in summer to $7.7^{\circ} \mathrm{C}$ in winter. The horizontal temperature exhibits the largest spatial difference in April $\left(\sim 20^{\circ} \mathrm{C}\right)$ and the lowest value in July $\left(\sim 4^{\circ} \mathrm{C}\right)$. Although the degree of spatial and temporal variability differed considerably between the seasons, the water temperature distributions 
exhibit a similar spatial pattern that the temperature generally decreases from the shallow floodplain areas to the lake's main flow channels, partly due to the influence of the lake water depth.

Sensitivity testing shows that air temperature, solar radiation, wind speed and the river temperature have significant effects on the water temperature response, and the response is distinctly different throughout the lake. In addition, other factors such as cloud cover, relative humidity, precipitation, evaporation and lake topography may play a complementary role of influencing temperature. This work presents a first work on the water temperature regimes of the large floodplain of Poyang Lake. Knowledge gained in this work will benefit future ecological and environmental management.

Acknowledgments: This work is jointly supported by the Collaborative Innovation Center for Major Ecological Security Issues of Jiangxi Province and Monitoring Implementation (JXS-EW-00), the Natural Science Foundation of Jiangsu Province (BK20141061) and the National Natural Science Foundation of China (41771037 and 41401031). We thank Poyang Lake Research Station for Wetland Ecosystem, Nanjing Institute of Geography and Limnology, Chinese Academy of Sciences, for providing the field data of water temperature used in this study. We also thank Prof. Chaoyang Fang from Jiangxi Normal University for collecting the routine water temperature data.

Author Contributions: All authors conceived of and designed the study. Yunliang Li, Qi Zhang and Jing Yao made substantial contributions to the model simulations. Yunliang Li implemented the simulations. Zhiqiang Tan and Li Zhang made substantial contributions to the remote sensing analysis. All authors discussed the basic structure of the manuscript, and Yunliang Li wrote and edited the paper. All authors read and approved the submitted manuscript.

Conflicts of Interest: The authors declare no conflict of interest.

\section{References}

1. Willamson, C.E.; Dodds, W.; Kratz, T.K.; Palmer, M.A. Lakes and streams as sentinels of environmental change in terrestrial and atmospheric processes. Front. Ecol. Environ. 2008, 6, 247-254. [CrossRef]

2. Adrian, R.; OReilly, C.M.; Zagarese, H.; Baines, S.B.; Hessen, D.O.; Keller, W.; Livingstone, D.M.; Sommaruga, R.; Straile, D.; Van Donk, E.; et al. Lakes as sentinels of climate change. Limnol. Oceanogr. 2009, 54, 2283-2297. [CrossRef] [PubMed]

3. Woolway, R.I.; Merchant, C.J. Amplified surface temperature response of cold, deep lakes to inter-annual air temperature variability. Sci. Rep. 2017, 7, 1-8. [CrossRef] [PubMed]

4. Sima, S.; Ahmadalipour, A.; Tajrishy, M. Mapping surface temperature in a hyper-saline lake and investigating the effect of temperature distribution on the lake evaporation. Remote Sens. Environ. 2013, 136, 374-385. [CrossRef]

5. Allan, M.G.; Hamilton, D.P.; Trolle, D.; Muraoka, K. Spatial heterogeneity in geothermally-influenced lakes derived from atmospherically corrected Landsat thermal imagery and three-dimensional hydrodynamic modelling. Int. J. Appl. Earth Obs. 2016, 50, 106-116. [CrossRef]

6. Trumpickas, J.; Shuter, B.J.; Minns, C.K. Foresting impacts of climate change on Great Lakes surface water temperature. J. Great Lakes Res. 2009, 35, 454-463. [CrossRef]

7. Hlevca, B.; Cooke, S.J.; Midwood, J.D.; Doka, S.E.; Portiss, R.; Wells, M.G. Characterisation of water temperature variability within a harbour connected to a large lake. J. Great Lakes Res. 2015, 41, 1010-1023. [CrossRef]

8. Coll, C.; Caselles, V.; Galve, J.M.; Valor, E.; Niclòs, R.; Sánchez, J.M.; Rivas, R. Ground measurements for the validation of land surface temperatures derived from AATSR and MODIS data. Remote Sens. Environ. 2005, 97, 288-300. [CrossRef]

9. Schneider, P.; Hook, S.J. Space observations of inland water bodies show rapid surface warming since 1985. Geophys. Res. Lett. 2010, 37, L22405. [CrossRef]

10. Safaie, A.; Litchman, E.; Phanikumar, M.S. Evaluating the role of groundwater on circulation and thermal structure in a deep inland lake. Adv. Water Resour. 2017, 108, 310-327. [CrossRef]

11. Webb, B.W.; Hannah, D.M.; Moore, R.D.; Brown, L.E.; Nobilis, F. Recent advances in stream and river temperature research. Hydrol. Process. 2008, 22, 902-918. [CrossRef]

12. Javaheri, A.; Babbar-Sebens, M.; Miller, R.N. From skin to bulk: An adjustment technique for assimilation of satellite-derived temperature observations in numerical models of small inland water bodies. Adv. Water Resour. 2016, 92, 284-298. [CrossRef] 
13. MacCallum, S.N.; Merchant, C.J. Surface water temperature observations of large lakes by optimal estimation. Can. J. Remote Sens. 2012, 38, 25-44. [CrossRef]

14. Torbick, N.; Ziniti, B.; Wu, S.; Linder, E. Spatiotemporal lake skin summer temperature trends in the northeast United States. Earth Interact. 2016, 20, 1-21. [CrossRef]

15. Politi, E.; Cutler, M.E.J.; Rowan, J.S. Using the NOAA Advanced Very High Resolution Radiometer to characterise temporal and spatial trends in water temperature of large European lakes. Remote Sens. Environ. 2012, 126, 1-11. [CrossRef]

16. Moukomla, S.; Blanken, P.D. Remote sensing of the North American Laurentian Great Lakes' surface temperature. Remote Sens. 2016, 8, 286. [CrossRef]

17. Riffler, M.; Lieberherr, G.; Wunderle, S. Lake surface water temperatures of European Alpine lakes (1989-2013) based on the Advanced Very High Resolution Radiometer (AVHRR) 1 km data set. Earth Syst. Sci. Data 2015, 7,1-17. [CrossRef]

18. Mahanty, M.M.; Mohanty, P.K.; Pattnaik, A.K.; Panda, U.S.; Pradhan, S.; Samal, R.N. Hydrodynamics, temperature/salinity variability and residence time in the Chilika lagoon during dry and wet period: Measurement and modelling. Cont. Shelf Res. 2016, 125, 28-43. [CrossRef]

19. Bueche, T.; Vetter, M. Simulating water surface temperature and stratification of a pre-alpine lake with a hydrodynamic model: Calibration and sensitivity analysis of climatic input parameters. Hydrol. Process. 2014, 28, 1450-1464. [CrossRef]

20. Xue, P.; Schwab, D.J.; Hu, S. An investigation of the thermal response to meteorological forcing in a hydrodynamic model of Lake Superior. J. Geophys. Res. Oceans 2015, 120, 5233-5253. [CrossRef]

21. Zhong, Y.; Notaro, M.; Vavrus, S.; Foster, M.J. Recent accelerated warming of the Laurentian Great Lakes: Physical drivers. Limnol. Oceanogr. 2016, 61, 1762-1786. [CrossRef]

22. Pahlevan, N.; Garrett, A.J.; Gerace, A.D.; Schott, J.R. Integrating Landsat-7 imagery with physics-based models for quantitative mapping of coastal waters near river discharges. Photogramm. Eng. Remote Sens. 2012, 78, 1163-1174. [CrossRef]

23. Weinberger, S.; Vetter, M. Using the hydrodynamic model DYRESM based on results of a regional climate model to estimate water temperature changes at Lake Ammersee. Ecol. Model. 2012, 244, 38-48. [CrossRef]

24. Buccola, N.L.; Risley, J.C.; Rounds, S.A. Simulating future water temperatures in the North Santiam River, Oregon. J. Hydrol. 2016, 535, 318-330. [CrossRef]

25. Shankman, D.; Heim, B.D.; Song, J. Flood frequency in China's Poyang Lake region: Trends and teleconnections. Int. J. Climatol. 2006, 26, 1255-1266. [CrossRef]

26. Feng, L.; Hu, C.; Chen, X.; Cai, X.; Tian, L.; Gan, W. Assessment of inundation changes of Poyang Lake using MODIS observation between 2000 and 2010. Remote Sens. Environ. 2012, 121, 80-92. [CrossRef]

27. Guo, H.; Hu, Q.; Zhang, Q.; Feng, S. Effects of the Three Gorges Dam on Yangtze River flow and river interaction with Poyang Lake, China: 2003-2008. J. Hydrol. 2012, 416-417, 19-27. [CrossRef]

28. Zhang, Q.; Ye, X.C.; Werner, A.D.; Li, Y.L.; Yao, J.; Li, X.H.; Xun, C.Y. An investigation of enhanced recessions in Poyang Lake: Comparison of Yangtze River and local catchment impacts. J. Hydrol. 2014, 517, $425-434$. [CrossRef]

29. Cheng, X.; Li, S. An analysis on the evolvement processes of lake eutrophication and their characteristics of the typical lakes in the middle and lower reaches of Yangtze River. Chin. Sci. Bull. 2006, 51, 1603-1613. [CrossRef]

30. Yao, X.; Wang, S.; Ni, Z.; Jiao, L. The response of water quality variation in Poyang Lake (Jiangxi, People's Republic of China) to hydrological changes using historical data and DOM fluorescence. Environ. Sci. Pollut. Res. 2015, 22, 3032-3042. [CrossRef] [PubMed]

31. Liu, X.; Li, Y.L.; Liu, B.G.; Qian, K.M.; Chen, Y.W.; Gao, J.F. Cyanobacteria in the complex river-connected Poyang Lake: Horizontal distribution and transport. Hydrobiologia 2016, 768, 95-110. [CrossRef]

32. Wu, Z.; Lai, X.; Zhang, L.; Cai, Y.; Chen, Y. Phytoplankton chlorophyll a in Lake Poyang and its tributaries during dry, mid-dry and wet seasons: A 4-year study. Knowl. Manag. Aquat. Ecosyst. 2014, 412, 1-13.

33. Li, B.; Yang, G.; Wan, R.; Hörmann, G.; Huang, J.; Fohrer, N.; Zhang, L. Combining multivariate statistical techniques and random forests model to asses and diagnose the trophic status of Poyang Lake in China. Ecol. Indic. 2017, 83, 74-83. [CrossRef] 
34. Kanai, Y.; Ueta, M.; Germogenov, N.; Nagendran, M.; Mita, N.; Higuchi, H. Migration routes and important resting areas of Siberian cranes (Grus leucogeranus) between northeastern Siberia and China as revealed by satellite tracking. Biol. Conserv. 2002, 106, 339-346. [CrossRef]

35. Zhen, L.; Li, F.; Huang, H.; Dilly, O.; Liu, J.; Wei, Y.; Yang, L.; Cao, X. Households' willingness to reduce pollution threats in the Poyang Lake region, southern China. J. Geochem. Explor. 2011, 110, 15-22. [CrossRef]

36. Li, Y.L.; Zhang, Q.; Werner, A.D.; Yao, J.; Ye, X.C. The influence of river-to-lake backflow on the hydrodynamics of a large floodplain lake system (Poyang Lake, China). Hydrol. Process. 2017, 31, 117-132. [CrossRef]

37. Chen, M.; Wei, X.; Huang, H.; Lu, T. Poyang Lake basin: A successful, large-scale integrated basin management model for developing counties. Water Sci. Technol. 2011, 63, 1899-1905. [CrossRef] [PubMed]

38. Woolway, R.I.; Maberly, S.C.; Jones, I.D.; Feuchtmayr, H. A novel method for estimating the onset of thermal stratification in lakes from surface water measurements. Water Resour. Res. 2014, 50, 5131-5140. [CrossRef]

39. Li, Y.L.; Yao, J.; Zhang, L. Investigation into mixing in the shallow floodplain Poyang Lake (China) using hydrological, thermal and isotopic evidence. Water Sci. Technol. 2016, 74, 2582-2598. [CrossRef] [PubMed]

40. Li, Y.L.; Zhang, Q.; Werner, A.D.; Yao, J. Investigating a complex lake-catchment-river system using artificial neural networks: Poyang Lake (China). Hydrol. Res. 2015, 46, 912-928. [CrossRef]

41. Hu, Q.; Feng, S.; Guo, H.; Chen, G.Y.; Jiang, T. Interactions of the Yangtze River flow and hydrologic processes of the Poyang Lake, China. J. Hydrol. 2007, 347, 90-100. [CrossRef]

42. Li, Y.L.; Zhang, Q.; Yao, J.; Werner, A.D.; Li, X.H. Hydrodynamic and hydrological modeling of Poyang Lake catchment system in China. J. Hydrol. Eng. 2014, 19, 607-616. [CrossRef]

43. Li, Y.L.; Zhang, Q.; Yao, J. Investigation of residence and travel time in a large floodplain lake with complex lake-river interactions: Poyang Lake (China). Water 2015, 7, 1991-2012. [CrossRef]

44. Wilson, J.; Rocha, C. Regional scale assessment of submarine groundwater discharge in Ireland combining medium resolution thermal imagery and geochemical tracing techniques. Remote Sens. Environ. 2012, 119, 21-34. [CrossRef]

45. Barsi, J.A.; Schott, J.R.; Palluconi, F.D.; Helder, D.L.; Hook, S.J.; Markham, B.L. Landsat TM and ETM+ thermal band calibration. Can. J. Remote Sens. 2003, 29, 141-153. [CrossRef]

46. Danish Hydraulic Institute (DHI). MIKE 21 Flow Model: Hydrodynamic Module User Guide; Danish Hydraulic Institute Water and Environment: Hørsholm, Denmark, 2014; p. 132.

47. Zhang, Q.; Werner, A.D. Hysteretic relationships in inundation dynamics for a large lake-floodplain system. J. Hydrol. 2015, 527, 160-171. [CrossRef]

48. Sahlberg, J. A Hydrodynamic Model for Heat Contents Calculations on Lakes at the Ice Formation Date; Document D4: 1984; Swedish Council for Building Research: Stockholm, Sweden, 1984.

49. Kantha, L.H.; Clayson, C.A. Small Scale Processes in Geophysical Fluid Flows; International Geophysics; Academic Press: Waltham, MA, USA, 2000; Volume 67.

50. Imberger, J. Thermal characteristics of standing waters: An illustration of dynamic processes. Hydrobiologia 1985, 125, 7-29. [CrossRef]

51. Feng, L.; Hu, C.; Chen, X.; Li, R.; Tian, L.; Murch, B. MODIS observations of the bottom topography and its inter-annual variability of Poyang Lake. Remote Sens. Environ. 2011, 115, 2729-2741. [CrossRef]

52. Jiao, L. Scientists line up against dam that would alter protected wetlands. Science 2009, 326, 508-509. [CrossRef] [PubMed]

(C) 2017 by the authors. Licensee MDPI, Basel, Switzerland. This article is an open access article distributed under the terms and conditions of the Creative Commons Attribution (CC BY) license (http://creativecommons.org/licenses/by/4.0/). 